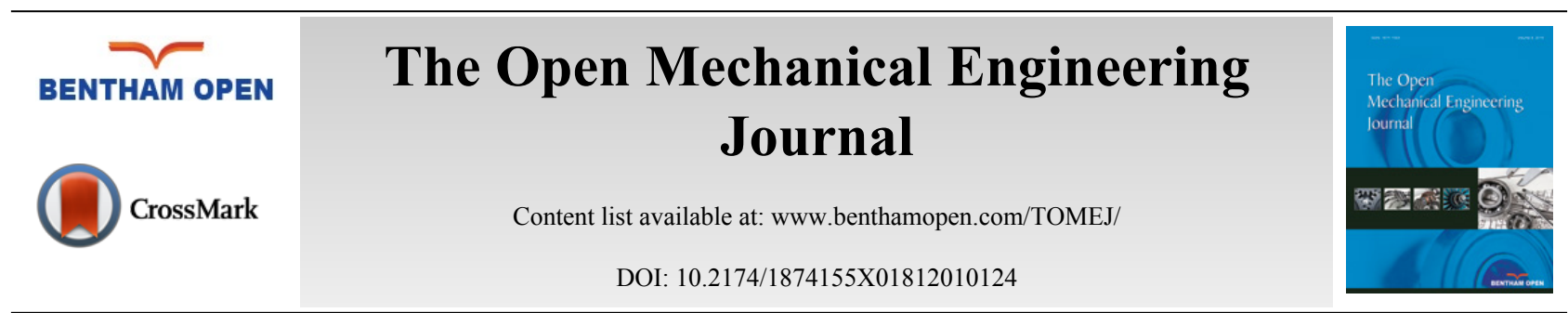

RESEARCH ARTICLE

\title{
Micro Hybridized Auto-rickshaw for Bangladesh: A Solution to Green Energy Vehicle
}

\author{
Avijit Mallik ${ }^{*}$ and Arman Arefin \\ Department of Mechanical Engineering, RUET, Rajshahi-6204, Bangladesh
}

Received: November 20, 2017

Revised: April 26, 2018

Accepted: April 27, 2018

\begin{abstract}
:
Background:

Auto rickshaws are compact, three-wheeled vehicles which are normally used altogether in numerous Asian nations (i.e. China, Japan, Bangladesh, India, Pakistan and so forth) for transportation of people and products. The vehicles are little and have simple transportability in occupied Asian cities. In Bangladesh, auto rickshaws/simple bicycles regularly offer their taxi services, as they are fantastically reasonable to work. Simultaneously, these three-wheelers running on fuel cause extreme air-pollution and create impressive measures of greenhouse gasses (i.e. Carbon dioxide).
\end{abstract}

\section{Objectives:}

This paper introduces a transportation system in view of auto rickshaws that work in an eco-accommodating way. Existing vehicles are to be substituted by a small scale-cross sort framework overhauled in a way which helps the productivity of the vehicle.

\section{Methods:}

A reviving foundation is suggested that will take into consideration the power-packs to be charged utilizing halfway energy, for example, solar energy. Necessary simulations had been done using MATLAB platform.

Results:

Results shows that the current vehicle and nature, in which it works, made a model of the vehicle and researched re-charging infrastructure prerequisites and plans. About $31 \%$ efficiency was observed.

\section{Conclusions:}

The objective of the research introduced in this paper is to build up a conservative, vigorous and feasible fuel utilization system and deplete auto-rickshaws. In this research, $23 \%$ of grid power savings has been found.

Keywords: Solar power, Hybrid, Micro-hybrid, Auto-rickshaw, Environment friendly vehicle, Photovoltaics.

\section{INTRODUCTION}

With continued economic growth, all sectors of Bangladesh are developing day by day. With this development, megacities of the country are experiencing more traffic. Buses, Rickshaws and Auto-rickshaws (Electric or Internal Combustion Engine run) are the main public transports in megacities (i.e. Dhaka, Chittagong, Rajshahi) [1]. The autorickshaw and the relatively modern iteration of the e-rickshaw (electronic rickshaw) because of their low cost are becoming more popular than taxis in current century [2]. In Asian megacities, like Mumbai, Dhaka, Kolkata, Bengaluru and Chittagong; this vehicle is mostly used for medium travelling distance ( 1 to $7 \mathrm{~km}$ 's). Auto-rickshaws are a common

\footnotetext{
* Address correspondence to this author at the Department of Mechanical Engineering, RUET, Rajshahi-6204, Bangladesh; Tel: +8801876603829; E-mail: avijitme13@gmail.com
} 
means of public transportation in many developing countries in the world [1, 3].

Auto-rickshaw is a three wheeler mostly running on fuel (CNG/LPG) or electrical energy. Those running on batteries by means of electricity are often called "Easy Bikes", locally it is a very cost effective vehicle. LPG (Liquefied Petroleum Gas) and CNG (Compressed Natural Gas) are nonrenewable energy sources. At present in Bangladesh, the fuel price is increasing day by day. Burning of petrol, natural gas and oils produces carbon dioxide, which is responsible for global warming. Moreover, the exhaust gases release different types of deadly fluid aerosols and chemicals in the atmosphere which is very harmful for humans and animals $[4,5]$. Presently, there are many types, designs and variations in auto-rickshaws.

The best way to redesign the rickshaw is to make the key power source hybridized. One way to do this is to use an energy system that can take advantage of several sources of renewable energy; i.e. Solar energy, wind energy etc. Autorickshaws are a great prospect for electrification because of relatively low velocity and a relatively small distance protected in a day [6]. In this paper, a mechanism using micro hybrid system to run an engine driven rickshaw is shown and defined. Solar energy and thermal energy can be used to drive the auto-rickshaw jointly by means of hybridization. Solar energy is chosen here because Bangladesh gets huge amount of energy from the sun. Here, the best sunlight hours received in Khulna ranging from 2.86 to 9.04 hours and in Barisal it ranges from 2.65 to 8.75 hours [7]. Compared to other conventional vehicles, micro hybridized vehicles consume less energy and produces much less green house and toxic gases. However, a critical review of literature regarding several works done on auto-rickshaw in dissimilar fields is shown in Table $\mathbf{1}$.

Table 1. Different previous work done on Auto-rickshaw

\begin{tabular}{|c|c|c|c|}
\hline Year & Purpose of Study & Major Findings & References \\
\hline 2007 & $\begin{array}{l}\text { Worked on developing the usage pattern for three } \\
\text { wheeled auto-rickshaw in India. }\end{array}$ & $\begin{array}{l}\text { Designed a drive cycle for auto-rickshaw and validated the cycle by } \\
\text { Simulink software. }\end{array}$ & {$[8]$} \\
\hline 2009 & $\begin{array}{l}\text { Worked on micro-hybrid system installation on engine } \\
\text { operated auto-rickshaw. }\end{array}$ & Tested and made a prototype of micro-hybridized auto-rickshaw for India. & [9] \\
\hline 2010 & $\begin{array}{l}\text { Used solar PV modules in auto-rickshaw as a green } \\
\text { power source in normal electric auto-rickshaw. }\end{array}$ & $\begin{array}{l}\text { Designed and auto-rickshaw which was solar assisted and validated the } \\
\text { design by ADVISOR software. }\end{array}$ & {$[10]$} \\
\hline 2010 & $\begin{array}{l}\text { Analyzed on economic and social parameters of three- } \\
\text { wheeler taxi service. }\end{array}$ & $\begin{array}{l}\text { Surveyed on } 200 \text { operators and } 100 \text { passengers, it analyzed the positive } \\
\text { and negative aspects of these vehicles. }\end{array}$ & [11] \\
\hline 2012 & $\begin{array}{l}\text { Worked on time-dependent plug in hybrid electric } \\
\text { vehicle. }\end{array}$ & $\begin{array}{l}\text { Found a compact vehicle with } 10.4 \mathrm{KW} \text { useable batteries travels } 62.5 \% \text { to } \\
75.7 \% \text { on battery electricity, depending on charging scenario. }\end{array}$ & {$[12]$} \\
\hline 2012 & $\begin{array}{l}\text { Worked on the role of auto-rickshaw on sustainable } \\
\text { urban transport sector. }\end{array}$ & $\begin{array}{l}\text { Examined the role auto-rickshaw can play in sustainable urban transport } \\
\text { sector of India and found a very positive result. }\end{array}$ & {$[13]$} \\
\hline 2014 & $\begin{array}{l}\text { Worked on Hybrid energy assisted auto-rickshaw } \\
\text { three wheeler. }\end{array}$ & $\begin{array}{l}\text { They used plug-in hybrid technology along with PV panel and validated } \\
\text { the design by ADVISOR software. }\end{array}$ & {$[14]$} \\
\hline 2016 & $\begin{array}{l}\text { Worked on the emission factors of auto-rickshaws } \\
\text { using real world driving cycle. }\end{array}$ & $\begin{array}{l}\text { They used Indian driving cycle and modified Indian driving cycle for } \\
\text { predicting the emissions. In this study real-world DCs were developed for } \\
\text { motor cycles and auto-rickshaw. }\end{array}$ & {$[15]$} \\
\hline 2017 & Worked on solar assisted tri-wheeler rickshaw. & Made a prototype of a solar driven tri-cycle and tested its feasibility. & {$[16]$} \\
\hline 2017 & $\begin{array}{l}\text { Proposed a solar based micro-hybridized auto- } \\
\text { rickshaw. }\end{array}$ & $\begin{array}{l}\text { Mathematically analyzed the vehicle by adding a PV panel with micro- } \\
\text { hybrid technology and did a feasibility analysis for Bangladesh. }\end{array}$ & {$[6]$} \\
\hline
\end{tabular}

From Table 1, most of the works on auto-rickshaw comments about petroleum burning or renewable source driven vehicle. This research was directed from T. Hofman et al. 2009; which was focused on hybridization of engine operated auto-rickshaws for India, but this research didn’t mention any renewable source of input energy.

\subsection{Power Train of the Vehicle}

In this proposed vehicle, electrical and thermal energy sources are combined along with micro hybrid system. As energy sources ICE and Batteries are being used. These two power sources are hybridized. The battery is charged my means of national grid and solar energy. There are several hybridization methods available like Series, parallel, seriesparallel and complex; parallel hybridization is implemented here. The basic difference between a hybrid and a conventional vehicle is the braking system. Hybrid vehicles use regenerative braking system; an energy recovery module which slows down the vehicle by transforming its kinetic energy into a form and is used immediately to other works or stored for further use. Hybrid vehicles are less fuel consuming [17]. Fig. (1) shows the schematic diagram of the vehicle power train. 


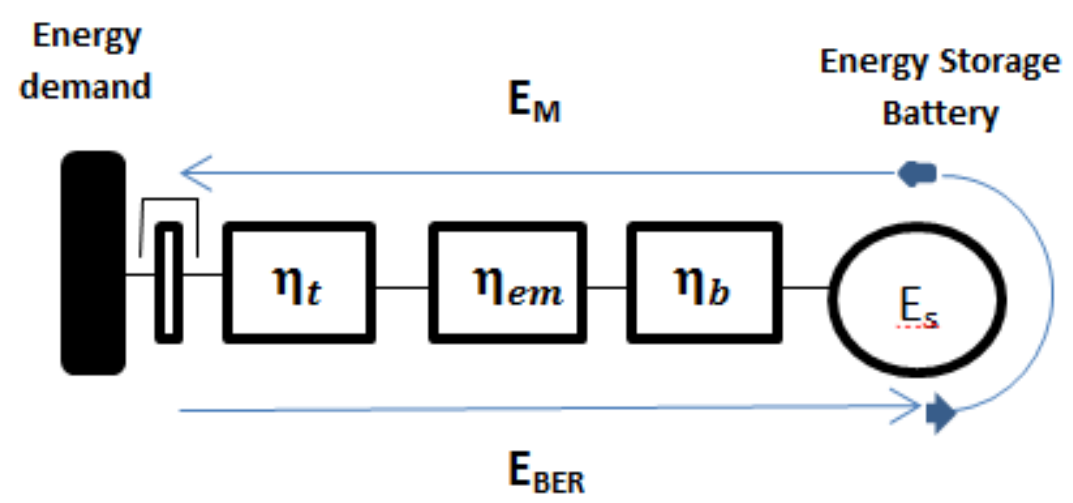

Fig. (1). Schematic diagram of the vehicle power train.

The fuel saving potential might be increased by recuperating brake energy and re-using this energy, $\mathrm{E}_{\mathrm{EBR}}$ denotes the recuperating brake energy (for electric driving). This electric energy is used for driving $\left(\mathrm{E}_{\mathrm{M}}\right)$. Fig. (1) shows the vehicle power drive.

This recuperating/regenerating brake energy is calculated over the drive cycle in $t_{f}$ time;

$$
E_{B E R}=-\int_{0}^{t_{f}} f_{b r} \cdot \min \left(0, P_{v}(t)\right) \cdot \eta_{t} \cdot \eta_{e m} \cdot \eta_{b} \cdot d t
$$

In the above equation (1), $f_{b r}$ denotes brake friction (regenerative). The subscripts denotes namely the transmission, electric motor and battery efficiency which is respectively assumed $98 \%, 85 \%$ and $80 \%$ average constant. The engine assumed here is "shut off kind" and has no drag losses due to electric driving and braking.

\subsection{Design Topology}

In addition to the element sizing and control engine optimization, the topology selection also plays an important role in the general hybrid drive train optimization. In Fig. (1), an understanding is given of different locations of joining the hybrid system to the drive coach. If more hybrid driving modes can be used, then fuel saving potential rises. Depending on the topology, a number hybrid functions can be utilized very well other functions increase difficulties. In Table 2, an overview is given on the pros and cons of different topologies. Through this qualitative comparison, it can be concluded that topologies 1,3 , and 5 perform the same and are therefore favorable. The topological table here is based on quality and nature of the spare parts.

A Table showing the topological analysis is give below:

\section{Table 2. Topological Analysis}

\begin{tabular}{|c|c|c|c|c|c|}
\hline Topological Options for Proposed Vehicle: $++=$ very good, $+=$ good, $-=$ bad, $\square=$ not possible & & & & & \\
\hline Topology & 1 & 2 & 3 & 4 & 5 \\
\hline Regenerative Braking & + & - & + & + & + \\
\hline Electric Driving & +++ & $\varnothing$ & + & +++ & ++ \\
\hline Charging (Driving) & + & ++ & ++ & + & + \\
\hline Easy Mounting & ++ & - & - & - & + \\
\hline Compacting & - & - & + & - & - \\
\hline Start-Stop & $\varnothing$ & ++ & ++ & $\varnothing$ & $\varnothing$ \\
\hline Motor-Assistance & + & + & + & ++ & ++ \\
\hline Possibility Score & $48 \%$ & $21 \%$ & $44 \%$ & $25 \%$ & $50 \%$ \\
\hline
\end{tabular}

Fig. (2) shows the topology designing of the proposed vehicle. The numbering indicates the possible locations of the components of the system. Here, ICE-Internal Combustion Engine, A-Alternator, FT-Fuel Tank of the vehicle, CLClutch (Wet-Plate type), BAT- Battery, Aux- Auxiliary Parts, MT- Manual Transmission. 


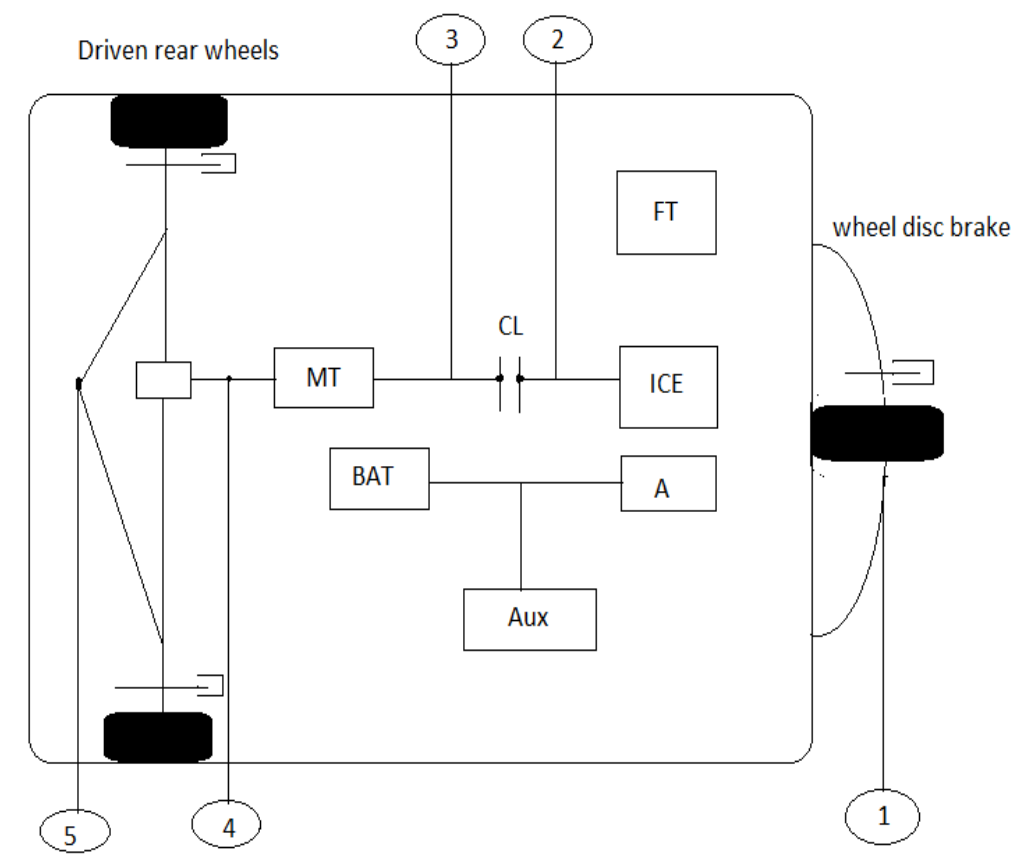

Fig. (2). Topology designing of the proposed vehicle.

\section{POWER ANALYSIS}

This paper focuses on micro hybridization of three-wheeler auto-rickshaw. Topology of the proposed system is shown in Table 2. This system has a conventional Internal Combustion Engine (ICE) and an electrical energy source namely, Li-ion battery used generally for medium load transfer. A micro hybrid vehicle uses a 'start-stop system', a regenerative breaking technology is applied here for stopping an ICE when the system pulls to stop and to restart it by pushing the accelerator. Here the proposed vehicle is being designed and the power calculations along with fuel consumption have been done under typical conditions and the parameters (with dimensioning) of the machine elements are given as per local market specifications available in Bangladesh.

\subsection{Engine Specifications, Testing of Performance with Simulation}

The specifications of the experimental engine are given below in Table $\mathbf{3}$ :

Table 3. Experimental Engine Specifications [18 - 20].

\begin{tabular}{|c|c|}
\hline Parameters & Dimension (SI unit) \\
\hline Piston Diameter & $.050228 \times 10^{-3}$ Meters \\
\hline Bore Radius & $0.025114 \times 10^{-3}$ Meters \\
\hline Length of the Bore & 0.046 Meters \\
\hline Length of Stroke & 0.042 Meters \\
\hline Cubic Capacity & $69.9 \times 10^{-6}$ Cubic Meters \\
\hline Type of Engine & 2 Strokes \\
\hline Number of Cylinders & 01 pcs \\
\hline Torque & $12.531 \mathrm{Nm}$ \\
\hline Engine Efficiency & $25 \%$ \\
\hline Fuel & Petrol/Octane \\
\hline Volume of Engine Cylinder & 19 Cubic Meters (Approximate) \\
\hline Brake Power & $2.61 \mathrm{~kW} @ 5000$ rpm speed \\
\hline
\end{tabular}

The performance of an ICE depends on various measures like bore, fuel consumption, Brake Mean Effective Pressure (BMEP), Displacement of piston and etc. Table 4 below shows the performance testing results of the engine stated in Table 3. 


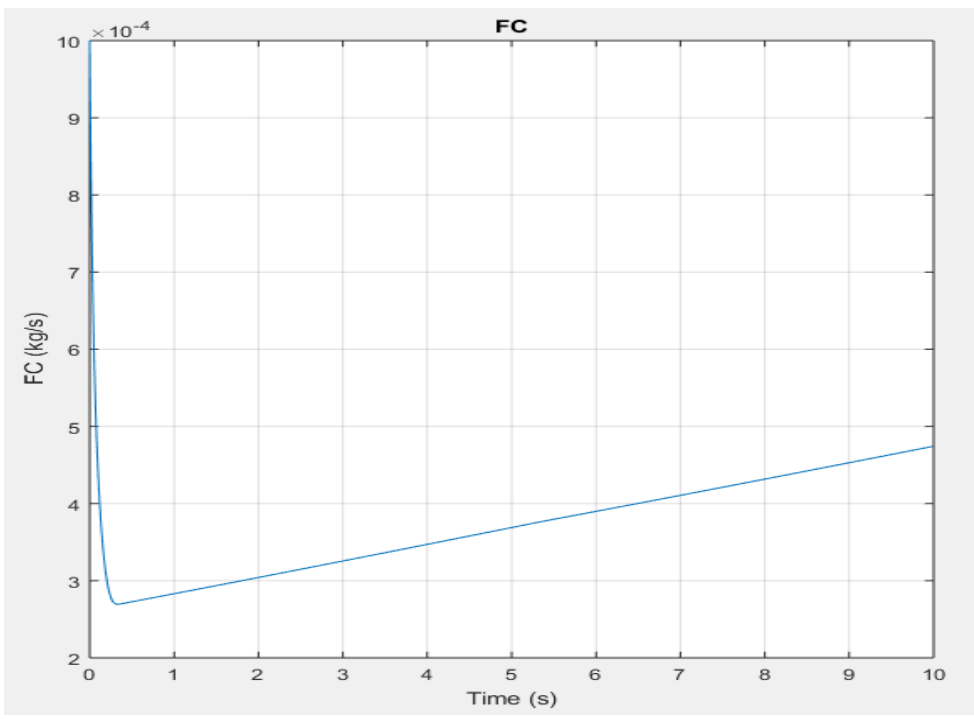

(a)

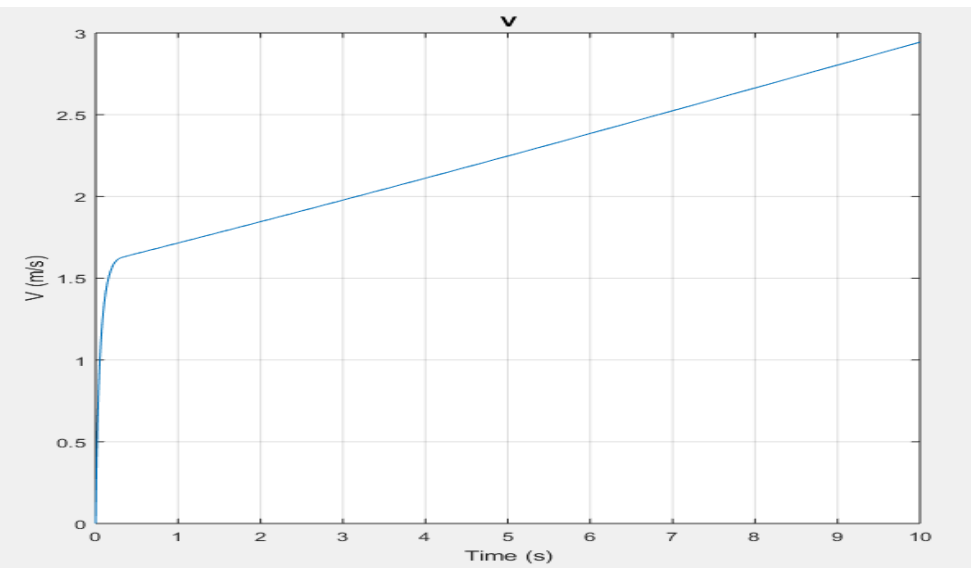

(b)

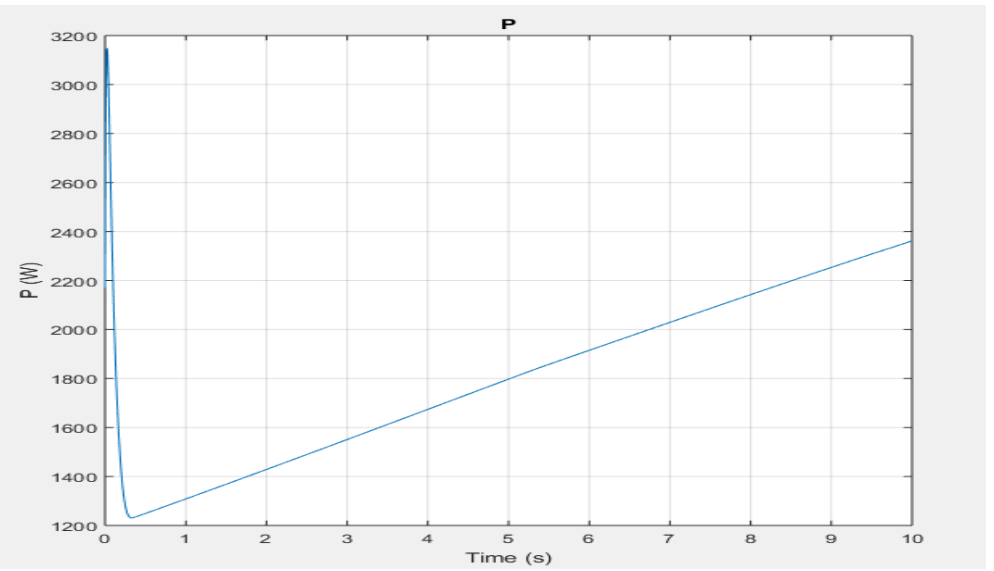

(c)

Fig. (3). Simulated results using Simulink platform. (a) Fuel Consumption vs time profile, (b) Velocity profile with respect to time and (c) Power consumption profile.

Vehicle simulation model driven by engine was done regarding the above data. The simulations were done using Simulink platform. For engine properties Table $\mathbf{3}$ and for vehicle properties Table 4 was used. Fig. (3) shows the simulated results. 
Table 4. Engine Performance Testing [21].

\begin{tabular}{|c|c|c|}
\hline Particulates & Equation & Value \\
\hline Displacement of Engine & $\pi \cdot S^{2} \cdot B \cdot n$ & Cubic Meters \\
\hline Stroke & $\frac{4 D}{\pi B^{2 n}}$ & 0.042 Meters \\
\hline Bore & $\frac{4 D}{\pi S n}$ & 0.046 Meters \\
\hline BMEP & $\begin{array}{l}(2 \pi \\
\times \text { Torque }) \\
/(\text { Displacement of Engine })\end{array}$ & $112977375 \mathrm{~Pa}$ \\
\hline Fuel Consumption & & $10 \mathrm{~kg} / \mathrm{hr}($ Assumed $)=0.014 \mathrm{~m}^{3} / \mathrm{h}\left(\right.$ As $\left.1 \mathrm{~kg} / \mathrm{sec}=5 \mathrm{~m}^{3} / \mathrm{hr}\right)$ \\
\hline Mass Flow Rate & $\begin{array}{l}\text { (Volume of Engine Cylinder } \\
\times \text { Sp.Gravity of Fuel) } \\
/(\text { Time } \times 1000)\end{array}$ & $0.014 \mathrm{~m}^{3} / \mathrm{hr}=.0028 \mathrm{~kg} / \mathrm{sec}$ \\
\hline Angular Velocity & $2 \pi \mathrm{N} / 60$ & $521.5 \mathrm{rad} / \mathrm{sec}(\mathrm{N}=$ Engine Speed in $\mathrm{rpm})$ \\
\hline S.P. Fuel Consumption & (Wt. of Fuel)/(Brake Power) & 0.036 kg/kW (Approximately) \\
\hline
\end{tabular}

\subsection{Solar Photovoltaic (PV) Module Specification and Power Consumption}

The battery used as electrical energy source will be charged in two ways, from National Grid and Solar PV module, respectively. A perfect designed PV module is needed to charge the batteries. The specifications of the PV module are given in the following Table 5 below.

Table 5. Photovoltaic Module Specifications [22, 23].

\begin{tabular}{|c|c|}
\hline Parameters & Dimension (SI units) \\
\hline Solar Panels & 2 Pcs \\
\hline Rated Output & $12 \mathrm{~V}-180 \mathrm{~W}$ (Total) \\
\hline Dimensions & $1.5 \times 0.8 \times 0.05 \mathrm{Meters}$ \\
\hline No. of Cells per Panel & $18 \%$ (Approximately) \\
\hline Efficiency & 24 Volts, 4 pcs \\
\hline Battery & 60 Mono Crystalline Cells \\
\hline No. of Solar Cells &
\end{tabular}

Power Consumption for PV module:

Let, The total weight of the proposed Vehicle $=500 \mathrm{~kg}$ (including all mountings and passengers)

Average speed $=35 \mathrm{kmph}$

Total Power $=$ Total weight of vehicle $\times \mathrm{g} \times$ speed $\times$ gradient of velocity

$=500 \times 9.8 \times 35 \mathrm{kmph} \times .03$ Watts

$=500 \times 9.8 \times 9.7 \mathrm{kmps} \times .03$ Watts

$=1426$ Watts

Here, the induction motor used is of $12 \mathrm{~V}-1 \mathrm{~kW}$ rated.

Current Flow $=\frac{\mathrm{P}}{\mathrm{V}}=\frac{1500}{36} \approx 42$ Amp.

Load Current per Day $=$ Current Flow $\times$ Running Time per Day $\times 1.2$

$=42 \times 5 \mathrm{hrs} \times 1.2250 \mathrm{Amp} . \mathrm{hrs} /$ Day 
Capacity of the Battery $=$ Load Current per Day $\times 1.2 \approx 300$ Amp.hrs/Day (overall 25\% losses)

Power required to run the motor $=$ Capacity of Battery $\times$ Voltage Difference

$=250 \times 36=9000 \mathrm{Whrs} /$ Day

No. of Batteries to be used $=\frac{1430}{378}=4 \mathrm{pcs}$

Now, here The Capacity of Solar Panel is $12 \mathrm{~V}-180 \mathrm{~W}$,

Current Flow $=(180 / 12) / 4=3.75$ Amp to each Battery

Charging Time $=250 / 3.75=66.67 \mathrm{hrs}$

If one Solar Panel is used then in $8 \mathrm{hrs}$ of daylight the system will be charged $\frac{100 \times 8}{73.8}$ or $12 \%$. But if the numbers of solar panels are increased then this charging would be more efficient. This percentage of charging can be increased by increasing the number of solar panels. If two solar panels are used, then the system will be charged $24 \%$ using PV module.

\section{RECHARGING INFRASTRUCTURE AND DRIVE CYCLE}

This proposed power plant is designed according to charge 50 auto-rickshaws. As stated above, this type of auto rickshaw needs around 1430 Watts power to run 5 hours/day. If we want to provide the full power from solar charging then the power plant capacity should be $(50 * 1430)=71.5 \mathrm{~kW}$.

A set of $18,5 \mathrm{~kW}$ solar modules will be used to make the power station. The total output will be $90 * 0.9=81 \mathrm{~kW}$ [24].

Fig. (4) shows the diagram of recharging infrastructure suitable for Bangladesh.
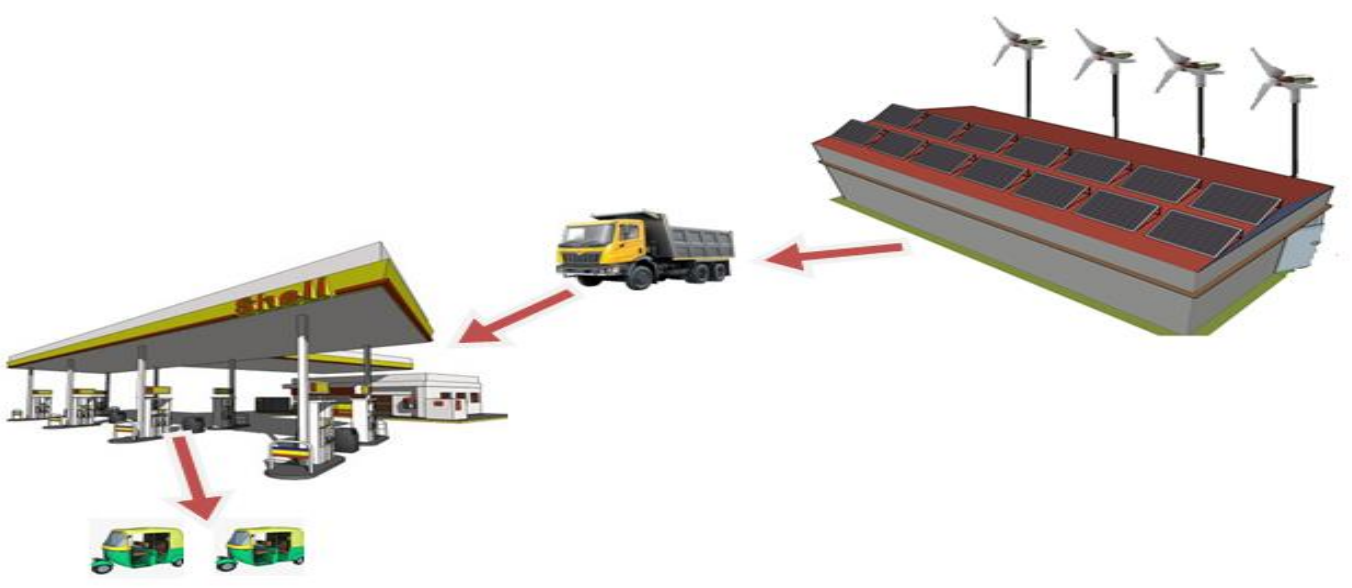

Fig. (4). Recharging infrastructure for proposed vehicle.

In this situation, a rickshaw administrator would go to neighborhood power stations (potentially the current service stations), where his released batteries would be swapped with completely charged batteries. The completely charged batteries would be brought from an off-site reviving station to the administration stations by electric truck, as shown in Fig. (4) $[10,25]$.

There are a few objectives set for the outline of the energizing station:

1. The battery replacing procedure must be as easy as filling the tank with fuel to a rickshaw driver. In Bangladesh most of the drivers are not skilled.

2. The use of renewable energy sources should be increased in Bangladesh to reduce the pressure on nonconventional energy sources.

3. In addition, in Bangladesh grid energy is not available in every place. This type of power station is effective in 
rural places.

Table 6. Optimizing Recharging Station Components [10, 25, 26]

\begin{tabular}{|c|c|c|c|}
\hline & PV & Wind & Gen \\
\hline Size (kW) & 600 & 438 & 350 \\
\hline Output (MWh/yr) & 1288 & 1128 & 896 \\
\hline Excess (\%, MWh) & & $4.82,150$ & \\
\hline \% Renewable & & 73 & \\
\hline
\end{tabular}

Table 6 shows the optimization of recharging components. For the re-charging solar and wind energy systems are used in combination. For avoiding connection to grid, propane generator is used as an energy buffer.

Drive cycle is assumed to be a vital part in outlining of a hybrid drive train. Normally, the auto-rickshaws go around 50-60 km per day. The federal test FTP-75 is used here to conduct the drive cycle considering typical auto-rickshaw dimensions and parameters and road conditions in Bangladesh. The normal drive cycle speed is taken $25 \mathrm{Km} / \mathrm{hr}$, which compares the internal city activity circumstance. Drive cycle and drive power demand were done using ADVISOR platform.

Fig. (5) represents the graphical model of urban drive cycle. The drive cycle and the vehicle specifications listed in Tables $\mathbf{2}$ and $\mathbf{3}$ can be used to calculate the wheel torque, $T_{w}$ as follows:

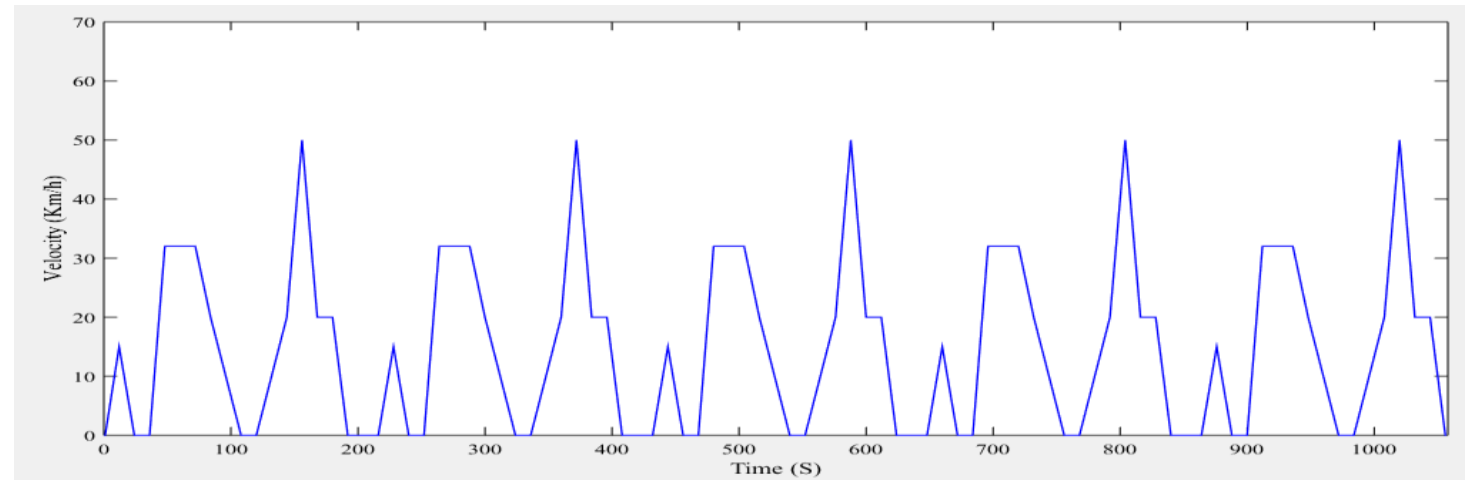

Fig. (5). Urban part of modified Bangladeshi drive cycle.

$\mathrm{T}_{\mathrm{W}}(\mathrm{t})=\mathrm{C}_{\mathrm{r}} \cdot \mathrm{M}_{\mathrm{V}} \cdot \mathrm{g} \cdot \mathrm{R}_{\mathrm{W}}+(1 / 2) \cdot[25]$

Where, $\mathrm{g}=$ gravitaional accelertion

$\mathrm{p}=$ air density $\left(1.225 \mathrm{~kg} / \mathrm{m}^{3}\right)$

And wheel speed,

$$
\omega_{\mathrm{v}}(\mathrm{t})=\frac{\mathrm{v}(\mathrm{t})}{\mathrm{R}_{\mathrm{w}}}
$$

The drive power demand is, $\mathrm{P}=\mathrm{T}_{\mathrm{W}}(\mathrm{t}) \cdot \mathrm{\omega}_{\mathrm{V}}(\mathrm{t})$

In Fig. (6), the drive power request is computed at every moment for the whole length of the drive cycle. The drive power demand is utilized to compute the braking energy that is accessible for regeneration and henceforth select the extent of the energy storage system. 


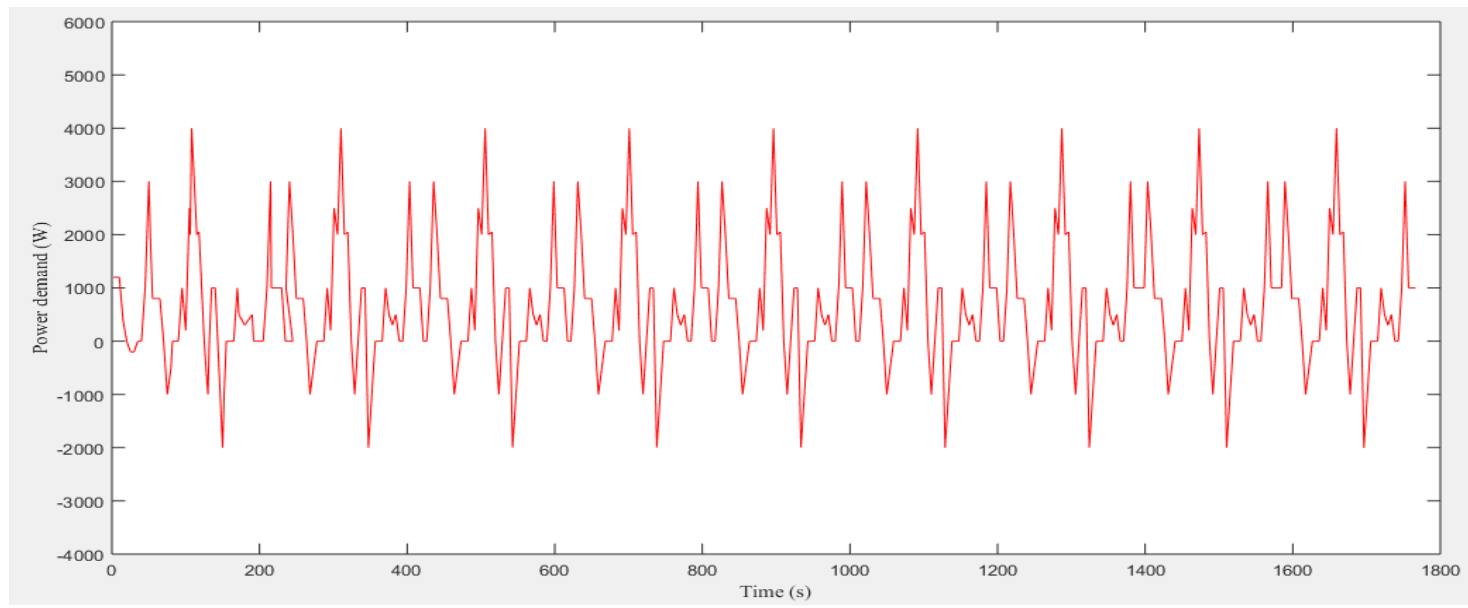

Fig. (6). Drive power demand.

\section{FEASIBILITY ANALYSIS}

Feasibility is an analysis and evaluation of a proposed system to determine if it is (1) technically possible to make, (2) is practicable within the estimated cost, and (3) will gain profit. Feasibility studies are almost always conducted where the proposed system has some possibility of break-down issue [27].

Here we have considered installation cost and environmental risk as variable measure. If the installation cost of micro-hybrid to a conventional engine operated auto-rickshaw has a bearable cost and the payback period of this excess cost is suitable then this system would be cost-effective.

\subsection{Installation Cost Calculations}

In this section, installation cost of micro-hybrid system to a conventional engine operated vehicle is shown. Table 7 shows the cost assumptions for installing micro-hybrid system:

Table 7. Cost estimation of new component installation.

\begin{tabular}{|c|l|}
\hline Component & \multicolumn{1}{c|}{ Cost } \\
\hline Micro-hybrid system & Nearly same as normal gearing arrangement of conventional ICE operated auto-rickshaw. \\
\hline PV Panel, 12V-180W (per pcs) & 7000 BDT (Nearly 84.30 USD) \\
\hline Battery, 36V (per pcs) & 8000 BDT (Nearly 96.34 USD) \\
\hline Induction Motor, 12V-1kW (1 pcs) & 7000 BDT (Nearly 84.30 USD) \\
\hline
\end{tabular}

Here, as micro-hybrid system costs nearly the same of conventional gearing arrangement of ICE operated autorickshaw, so this cost can be omitted for the simplicity of cost estimation of new component installation.

In this system, it typically needs:

1-2 pcs of PV Panel(s) +4 pcs of Battery +1 pcs of Induction Motor $=46000-53000$ BDT (554-638 USD approximately)

Thus, maximum installation cost of the proposed vehicle is 53000 BDT (Nearly 638 USD).

\subsection{Payback Period of New Installation Cost}

Payback period is the time required for the amount invested in an asset to be repaid by the net cash flow generated by the asset. It is a very simple way to evaluate the risk associated with a proposed project. An investment with a shorter payback period is considered to be better, since the investor's initial outlay is at risk for a shorter period of time $[28,29]$.

Formula of payback period is,

$$
\text { Payback Period }=\{(p-n) / p\}+n_{y}=\left\{1+n_{y}-(n / p)\right\} \quad \text { (unit: yrs) }
$$


Here,

$\mathrm{n}_{\mathrm{y}}=$ The number of years after the initial investment at which the last negative value of cumulative cash flow occurs.

$\mathrm{n}=$ The value of cumulative cash flow at which the last negative value of cumulative cash flow occurs.

$p=$ The value of cash flow at which the first positive value of cumulative cash flow occurs.

In this proposed vehicle,

Total power calculated to run the system $=1426$ Watts

Power required to run the motor $9 \mathrm{kwatts} . \mathrm{hr} / \mathrm{day}=9$ unit

In Bangladesh, commercial electric line cost 25 bdt/unit [Source: DESCO, https://www.desco.org.bd/ ]

Requires $=9000 / 5 * 36 * 4=12.5$ hours to charge the full battery.

Cost to charge the battery $=12.5 * 25=312.5 \mathrm{bdt} / \mathrm{day}$

Table 8 shows the payback period for the system.

Table 8. Estimation of payback period against new installing cost.

\begin{tabular}{|c|c|c|}
\hline Parameters & Case-1 & Case-2 \\
\hline PV Panels & $1 \mathrm{pcs}$ & $2 \mathrm{pcs}$ \\
\hline Batteries & $4 \mathrm{pcs}$ & $4 \mathrm{pcs}$ \\
\hline Induction Motor & $1 \mathrm{pcs}$ & $1 \mathrm{pcs}$ \\
\hline Power Supply from PV Module (per day) & $12-14 \%$ of $9 \mathrm{~kW}$ & $25-30 \%$ of $9 \mathrm{~kW}$ \\
\hline Cost Reduction (per day) & $27-32$ BDT (around 0.35 USD) & $55-62$ BDT (around 0.73 USD) \\
\hline Payback Period (yr.) & Around 4-4.5 yrs. maximum & Around 2-2.5 yrs. maximum \\
\hline
\end{tabular}

From the analysis above, Case- 2 is more favorable.

Fig. (7) shows a graphical representation of Payback Period and Installation Cost.

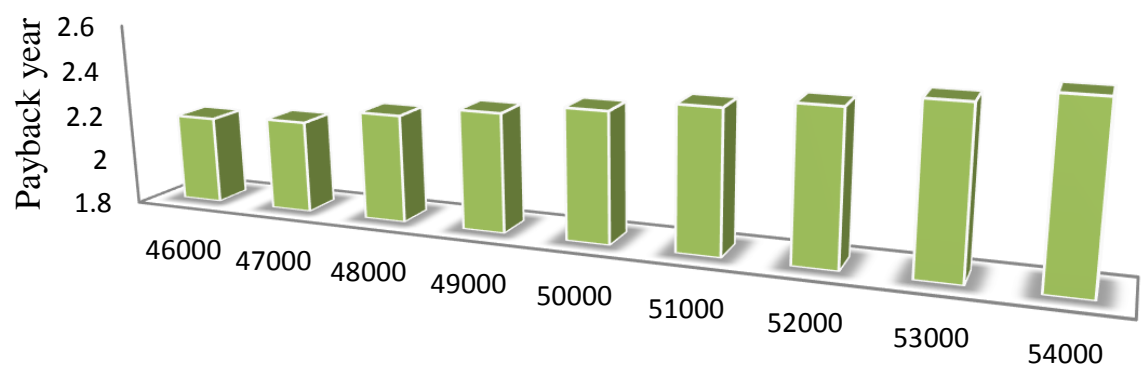

Installation Cost (BDT)

Fig. (7). Payback Period vs Installation Cost graph.

So, the payback time of this proposed system is between 2-2.5 years (approximately). A typical auto-rickshaw running age is between 18-20 years without much fluctuation in its performance [30]. Fig. (8) shows the relation between the running age and performance of a typical auto-rickshaw of Bangladesh. 


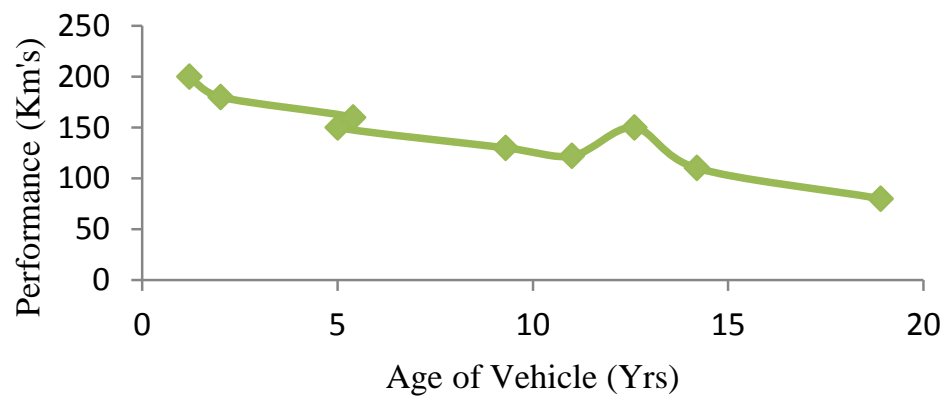

Fig. (8). Age vs Performance graph for sub-continental auto-rickshaws.

This proposed system needs 2-2.5 years to gain the installation cost, this payback time is only about $11-14 \%$ or less than $1 / 5^{\text {Th }}$ of the total running lifetime of an auto-rickshaw. So, this proposed system seems to be a profitable one by cost estimation.

\subsection{Environmental Impact Analysis}

Environmental impact analysis of a system is a mathematical prediction of that shows how much environment friendly that system is or how much harm can it cause. It is a very important factor regarding feasibility measurement of a system. This research is mainly focused on lessen the conventional energy consumption via using renewable energy in Bangladesh.

In Bangladesh, electricity is mainly produced by using thermal power plants. Those thermal power plants are a key source of $\mathrm{CO}_{2}$ gas emission resulting in enhanced greenhouse effect [4]. A $500 \mathrm{MW}$ thermal power plant can produce up to $1 \mathrm{~kg} / \mathrm{kWhr}$ production of electricity [31].

Fig. (9) gives a complete knowledge about $\mathrm{CO}_{2}$ emission from the power plants of Bangladesh.

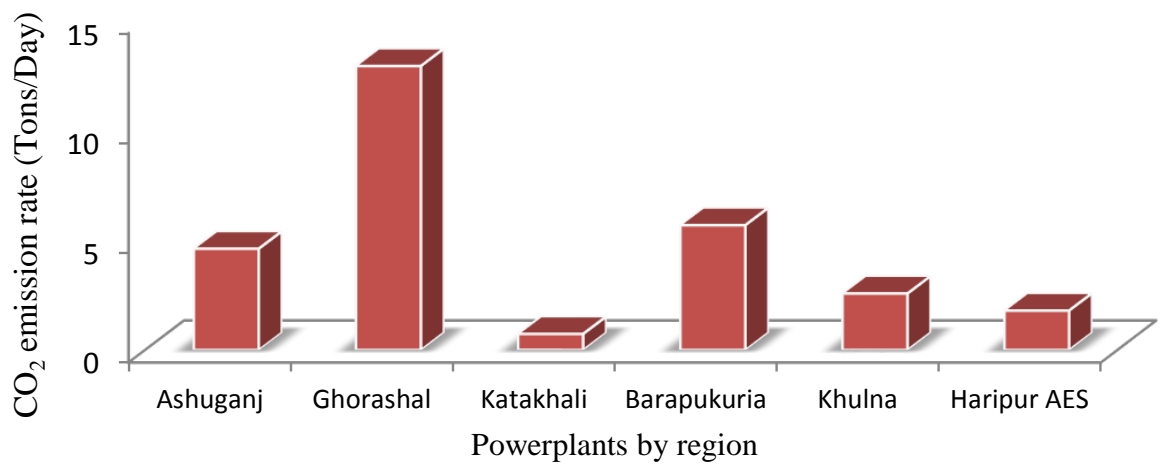

Fig. (9). $\mathrm{CO}_{2}$ emission rates of various power plants in Bangladesh [31 - 35].

All these properties are approximate and some are estimated.

Our proposed vehicle system offers about $24 \%$ less power consumption from National Grid. So, a huge number of these proposed vehicles will save more electrical energy resulting in less emission of $\mathrm{CO}_{2}$ from the fuel fired power plants.

Here, Katakhali Power Plant (Rajshahi) of 50MW capacity will be kept under consideration for calculation.

Assuming the plant as a 24 hrs/day working system,

Maximum electricity supplied by the plant $=50000 \mathrm{kWhr}$

The daily $\mathrm{CO}_{2}$ emission from Katakhali $=0.72399$ tons

Daily emission of $\mathrm{CO}_{2}$ per $\mathrm{kWh}$ energy $=\frac{\text { Daily } \mathrm{CO}_{2} \text { emission }}{\text { Capacity of the Plant per Day in } \mathrm{kWhr}}=1.44798 \times 10^{-5}$ tons 
Now, if this proposed vehicle system is implemented on Rajshahi City then, let, the numbers of proposed autorickshaws $=2000$ (estimated)

Energy savings per day per vehicle $=2.16 \mathrm{kWh}$ [From previous feasibility calculation]

Total energy savings per day $=(2000 * 2.16) \mathrm{kWh}=4320 \mathrm{kWh}$

$\mathrm{CO}_{2}$ emission to produce $4320 \mathrm{kWh}$ supply is $=$ tons $=0.062553$ tons (w.r.t. Katakhali Plant)

Lessen of $\mathrm{CO}_{2}$ emission from Katakhali via using this system $=\frac{0.062553}{0.72399} \times 100=8.64 \%$

From the above analysis, it can be surely said that the proposed vehicle system if implemented in Rajshahi City, then per day $\mathrm{CO}_{2}$ emission can be reduced upto $8.64 \%$ and power can be saved upto $4320 \mathrm{kWhr}$ per day. This analysis was performed considering no system loss; there remains a $25 \%$ system loss in thermal power plants. If the system loss is considered then actual percentage of $\mathrm{CO}_{2}$ emission lessens from Katakhali Plant will be about 20-22\%.

This feasibility analysis shows this system not only a cost effective but also an environment friendly one. This analysis mathematically proofs that vehicle system to be an effective one.

\subsection{Properties of Proposed Mechanism and Comparison with Other Systems}

Below Fig. (10), shows the special properties of the proposed vehicle.

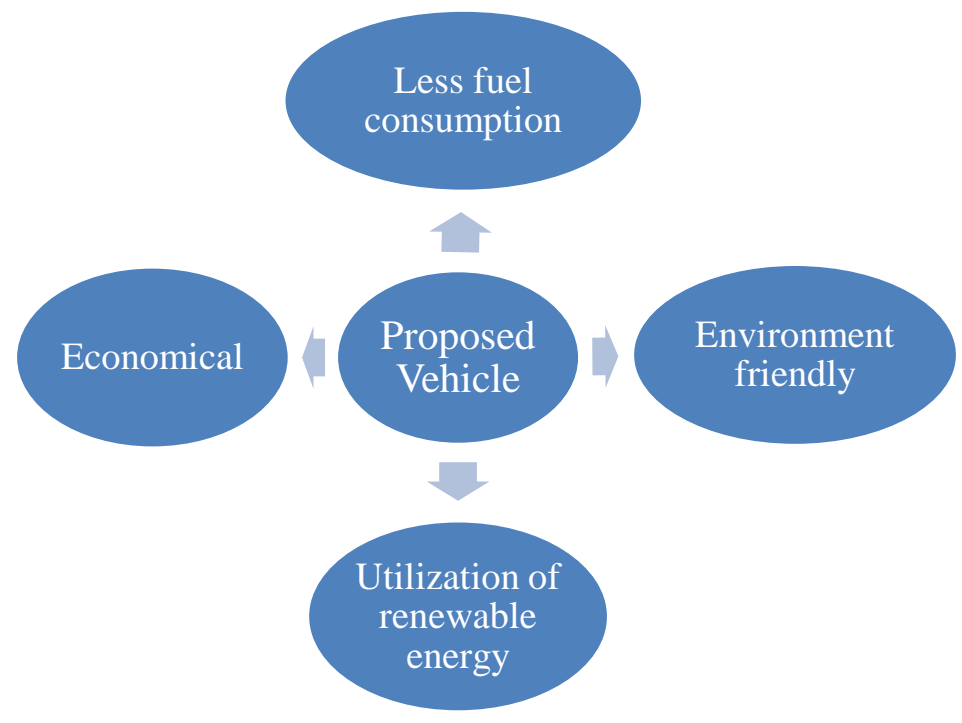

Fig. (10). Advantage of proposed vehicle.

Table 9 shows the differences among various types of auto-rickshaws with the proposed one's.

Table 9. Differences among typical (ICE), electrical and hybrid auto rickshaw.

\begin{tabular}{|c|c|c|}
\hline Typical (Engine Operated) & Electrical & Hybrid \\
\hline Huge amount of fuel consumption & $\begin{array}{c}\text { Electrical power is used which is not always } \\
\text { available in Bangladesh }\end{array}$ & $\begin{array}{c}\text { Uses both electrical and Thermal energy. So pressure } \\
\text { on only one energy source reduces }\end{array}$ \\
\hline It is pretty costly since fuel price is too high & $\begin{array}{c}\text { Takes a lot of Electrical energy to charge the } \\
\text { battery. so it can be considered costly too }\end{array}$ & $\begin{array}{c}\text { Less costly because the battery can also be charged by } \\
\text { solar energy. }\end{array}$ \\
\hline Not environment friendly & Environment friendly & More environment friendly than typical rickshaw \\
\hline Too much noise produces & Noise production less & Noise production less than typical one \\
\hline $\begin{array}{c}\text { Can carry more load than electrical Auto } \\
\text { rickshaw }\end{array}$ & Carries less load than both of them & Carry more load than electrical one \\
\hline Vibration more & No vibration & Less vibration \\
\hline
\end{tabular}




\section{CONCLUSION}

In the above described hybrid system, a whole system combined with an ICE and electrical power source (rechargeable battery can be charged by solar power and national grid) was used which is not so familiar from the perspective of Bangladesh. Some of the data were collected from different auto rickshaw driver. Some data were neglected which were far away from the majority. Quite similar mechanism now a day, can be seen in different automobiles but here the system is applied to a three wheeler. The system ensures the proper use of the solar energy. This vehicle could be a solution to the toxic greenhouse gases and particles. The vehicle would take the utilization of green energy to the next step, which would eventually help the world more safe and comfortable for living beings.

\section{CONSENT FOR PUBLICATION}

Not applicable.

\section{CONFLICT OF INTEREST}

The authors declare no conflict of interest, financial or otherwise.

\section{ACKNOWLEDGEMENTS}

We fell highly indebted and would like to acknowledge with due respect and gratitude the valuable and undeniable helps and guidelines received from Dr. Mohammad Uzzal Hossain Joardder, Assistant Professor, Department of Mechanical Engineering and other Teachers of Rajshahi University of Engineering \& Technology.

\section{REFERENCES}

[1] R. Basri, T. Khatun, M.S. Reza, and M.M.H. Khan, "Changing modes of transportation: A case study of rajshahi city corporation", Bangladesh J. Pol. Econ., vol. 29, no. 3, pp. 1-23, 2014.

[2] R. Brouwer, S. Akter, L. Brander, and E. Haque, "Socioeconomic vulnerability and adaptation to environmental risk: A case study of climate change and flooding in Bangladesh", Risk Anal., vol. 27, no. 2, pp. 313-326, 2007.

[http://dx.doi.org/10.1111/j.1539-6924.2007.00884.x] [PMID: 17511700]

[3] Md. Arefin, A. Mallik, A. Mujawar, and I. Rashid, "A case study nn ‘ dual energy source running Vehicle, It's design and implementation in Bangladesh", Int. J. Sci. Environ. Technol., vol. 6, no. 4, pp. 2369-2385, 2017.

[4] I.R. Mujawar, and M. Avijit, "Case study on greenhouse process, gases, effect and control management", Int. J. Innovative Res. Adv. Stud., vol. 4, no. 5, pp. 430-440, 2017.

[5] F. Ahmed, and H. Ishiga, "Trace metal concentrations in street dusts of Dhaka city, Bangladesh", Atmos. Environ., vol. 40, no. 21, pp. 3835-3844, 2006.

[http://dx.doi.org/10.1016/j.atmosenv.2006.03.004]

[6] M. Avijit, Md A. Arefin, and S. Kumar, "Solar based micro hybridized auto-rickshaw and its feasibility analysis for bangladesh", In: Proceedings of the Int. Conf. Mech. Eng. Ren. Energy (ICMERE), 2017. CUET, 18-20 December

[7] S.I. Sharif, A.R.A. Md, M. Al-Amin, and A.B.S. Md, "The prospect of renewable energy resources in bangladesh: A study to achieve the national power demand", Energy and Power, vol. 8, no. 1, pp. 1-6, 2018.

[http://dx.doi.org/10.5923/j.ep.20180801.01]

[8] S.M. Lukic, P. Mulhall, G. Choi, M. Naviwala, S. Nimmagadda, and A. Emadi, "Usage pattern development for three-wheel auto rickshaw taxis in India", In: Vehicle Power and Propulsion Conference, 2007. VPPC 2007. IEEE, IEEE, 2007, , pp. 610-616. [http://dx.doi.org/10.1109/VPPC.2007.4544195]

[9] T. Hofman, S.G. Van Der Tas, W. Ooms, E.W.P. Van Meijl, and B.M. Laugeman, "Development of a micro-hybrid system for a threewheeled motor taxi", World Electric Veh. J., vol. 3, no. 3, p. 1, 2009.

[10] P. Mulhall, S.M. Lukic, S.G. Wirasingha, Y.J. Lee, and A. Emadi, "Solar-assisted electric auto rickshaw three-wheeler", IEEE Trans. Vehicular Technol., vol. 59, no. 5, pp. 2298-2307, 2010. [http://dx.doi.org/10.1109/TVT.2010.2045138]

[11] A.S. Kumarage, M. Bandara, and D. Munasinghe, "Analysis of the economic and social parameters of the Three-wheeler Taxi service in Sri Lanka", Res. Transp. Econ., vol. 29, no. 1, pp. 395-400, 2010.

[http://dx.doi.org/10.1016/j.retrec.2010.07.050]

[12] J.C. Kelly, J.S. MacDonald, and G.A. Keoleian, "Time-dependent plug-in hybrid electric vehicle charging based on national driving patterns and demographics", Appl. Energy, vol. 94, pp. 395-405, 2012. [http://dx.doi.org/10.1016/j.apenergy.2012.02.001]

[13] A. Mani, M. Pai, and R. Aggarwal, "Sustainable urban transport in India: Role of the auto-rickshaw sector. ", PhD Thesis, World Recourses Institute, 20122018.http://www.wri.org/sites/default/files/pdf/sustainable_urban_transport_india.pdf 
[14] N. Shaha, and M.B. Uddin, "Hybrid energy assisted electric auto rickshaw three-wheeler", In: Electrical Information and Communication Technology, (EICT), 2013 International Conference on. IEEE, 2014, 2013.

[15] P. Adak, R. Sahu, and S.P. Elumalai, "Development of emission factors for motorcycles and shared auto-rickshaws using real-world driving cycle for a typical Indian city", Sci. Total Environ., vol. 544, pp. 299-308, 2016. [http://dx.doi.org/10.1016/j.scitotenv.2015.11.099] [PMID: 26657376]

[16] M.H. Masud, M.S. Akhter, S. Islam, A.M. Parvej, and S. Mahmud, "Design, construction and performance study of a solar assisted Tricycle", Period. Polytech. Mech. Eng., vol. 61, no. 3, pp. 234-241, 2017. [http://dx.doi.org/10.3311/PPme.10240]

[17] L.R. Brandenburg, and E.T. King, No. 5291960. U.S. Patent. Hybrid electric vehicle regenerative braking energy recovery system, 1994.

[18] M.L. Baglione, "Development of System Analysis Methodologies and Tools for Modeling and Optimizing Vehicle System Efficiency", PhD Thesis, University of Michigan, Michigan, 2007.

[19] Specifications of Bajaj Auto-rickshaw, Specifications of Bajaj Auto-rickshaw, https://www.bajajauto.com/bajajre/index.aspx, 2017.https://www.bajajauto.com/bajajre/index.aspx last accessed- 24/10/2017

[20] C.R. Ferguson, and A.T. Kirkpatrick, Internal combustion engines: Applied thermosciences, John Wiley \& Sons: New York, 2015, pp. $325-402$.

[21] R.S. Khurmi, and J.K. Gupta, A Textbook Of Thermal Engineering (Mechanical Technology)., S. Chand, 2008 , pp. 611-632.

[22] M.A. Green, Solar cells: Operating principles, technology, and system applications., 1982, pp. 63-94.

[23] Grameen Shakti Solar Co, https://www.gshakti.org, 2017.https://www.gshakti.org last accessed- 05/11/2017

[24] AliBaba Online Selling, https:/www.alibaba.com/product-detail/ Off-grid-5kw-solar-powergenerator803787671.html?spm=a 2700.7735675.30.21.3c420d3fsmKjds $\square$ s=p last accessed: 09/11/2017

[25] S.M. Lukic, P. Mulhall, and A. Emadi, "Energy autonomous solar/battery auto rickshaw", J. Asian Elect. Vehicles, vol. 6, no. 2, pp. 1135-1143, 2008. [http://dx.doi.org/10.4130/jaev.6.1135]

[26] Fernandez-Gamiz Unai, "Five megawatt wind turbine power output improvements by passive flow control devices", Energies, vol. 10, no. 6, p. $742,2017$.

[27] Feasibility Study (Business Dictionary), https://www.businessdictionary.com/definition/feasibility-study.html

[28] Payback Period (Accounting Tools), www.accountingtools.com/articles/2017/5/17/payback-method-payback-period-formula Last accessed$04 / 10 / 2017$

[29] M.U. Khan, M. Saleem, and N. Khan, "Establishment process strategies and profit or loss calculation of transport \& logistics company: a case of s-transporter of aligarh", Int. J. Manage. Res. Rev., vol. 7, no. 2, p. 134, 2017.

[30] M.A. Rahim, M.U.H. Joardder, S.M. Houque, M.M. Rahman, and N.A. Sumon, "Socio-economic \& environmental impacts of battery driven auto rickshaw at Rajshahi city in Bangladesh", In: International Conference on Mechanical, Industrial and Energy Engineering, KUET, Khulna, 2013.

[31] A.B. Rao, and E.S. Rubin, "A technical, economic, and environmental assessment of amine-based $\mathrm{CO}_{2}$ capture technology for power plant greenhouse gas control", Environ. Sci. Technol., vol. 36, no. 20, pp. 4467-4475, 2002. [http://dx.doi.org/10.1021/es0158861] [PMID: 12387425]

[32] S. Holloway, and H.E. Baily, “Coal bed methane pre-feasibility study-NW Bangladesh”, Technical Report Wc/95/59 R., British Geological Survey, Overseas Geology Series, 1995, pp. 1-26.

[33] R.R. Rahman, and M.A. Zaher, "Jamalganj Coal - its quantity, quality and minability. Petroleum and Mineral Resources of Bangladesh", In: Proceedings of the Seminar and Exhibition, 8-12 October, Peoples Republic of Bangladesh, 1980.

[34] M. Nazrul Islam, M. Nehal Uddin, S.A. Resan, and M. Sultan-Ul-Islam, "Geology of the Khalspir Coal Basin, Pirganj", Rec. Geol. Surv. Bangladesh, vol. 6, no. 5, 1991.Rangpur, Bangladesh

[35] P.S. Norman, Evaluation of the Barapukuria coal deposit NW Bangladesh.Case Histories and Methods in Mineral Resource evaluation.", Geological Society., vol. 63. Special Publication, 1992, pp. 107-120.

[http://dx.doi.org/10.1144/GSL.SP.1992.063.01.10]

(C) 2018 Mallik and Arefin.

This is an open access article distributed under the terms of the Creative Commons Attribution 4.0 International Public License (CC-BY 4.0), a copy of which is available at: (https://creativecommons.org/licenses/by/4.0/legalcode). This license permits unrestricted use, distribution, and reproduction in any medium, provided the original author and source are credited. 